\title{
Fuzzy-Probabilistic Calculations of Evapotranspiration
}

\author{
Boris Faybishenko \\ Lawrence Berkeley National Laboratory \\ Berkeley, CA \\ USA
}

\section{Introduction}

Evaluation of evapotranspiration uncertainty is needed for proper decision-making in the fields of water resources and climatic predictions (Buttafuoco et al., 2010; Or and Hanks, 1992; Zhu et al., 2007). However, in spite of the recent progress in soil-water and climatic uncertainty quantification, using stochastic simulations, the estimates of potential (reference) evapotranspiration $\left(E_{\mathrm{o}}\right)$ and actual evapotranspiration $(E T)$ using different methods/models, with input parameters presented as PDFs or fuzzy numbers, is a somewhat overlooked aspect of water-balance uncertainty evaluation (Kingston et al., 2009). One of the reasons for using a combination of different methods/models and presenting the final results as fuzzy numbers is that the selection of the model is often based on vague, inconsistent, incomplete, or subjective information. Such information would be insufficient for constructing a single reliable model with probability distributions, which, in turn, would limit the application of conventional stochastic methods.

Several alternative approaches for modeling complex systems with uncertain models and parameters have been developed over the past $\sim 50$ years, based on fuzzy set theory and possibility theory (Zadeh, 1978; 1986; Dubois \& Prade, 1994; Yager \& Kelman, 1996). Some of these approaches include the blending of fuzzy-interval analysis with probabilistic methods (Ferson \& Ginzburg, 1995; Ferson, 2002; Ferson et al., 2003). This type of analysis has recently been applied to hydrological research, risk assessment, and sustainable waterresource management under uncertainty (Chang, 2005), as well as to calculations of $E_{\mathrm{o}}$, ET, and infiltration (Faybishenko, 2010).

The objectives of this chapter are to illustrate the application of a combination of probability and possibility conceptual-mathematical approaches-using fuzzy-probabilistic modelsfor predictions of potential evapotranspiration $\left(E_{\mathrm{o}}\right)$ and actual evapotranspiration $(E T)$ and their uncertainties, and to compare the results of calculations with field evapotranspiration measurements.

As a case study, statistics based on monthly and annual climatic data from the Hanford site, Washington, USA, are used as input parameters into calculations of potential evapotranspiration, using the Bair-Robertson, Blaney-Criddle, Caprio, Hargreaves, Hamon, Jensen-Haise, Linacre, Makkink, Penman, Penman-Monteith, Priestly-Taylor, Thornthwaite, and Turc equations. These results are then used for calculations of evapotranspiration based on the modified Budyko (1974) model. Probabilistic calculations are performed using Monte 
Carlo and p-box approaches, and fuzzy-probabilistic and fuzzy simulations are conducted using the RAMAS Risk Calc code. Note that this work is a further extension of this author's recently published work (Faybishenko, 2007, 2010).

The structure of this chapter is as follows: Section 2 includes a review of semi-empirical equations describing potential evapotranspiration, and a modified Budyko's model for evaluating evapotranspiration. Section 3 includes a discussion of two types of uncertainties-epistemic and aleatory uncertainties-involved in assessing evapotranspiration, and a general approach to fuzzy-probabilistic simulations by means of combining possibility and probability approaches. Section 4 presents a summary of input parameters and the results of $E_{\mathrm{o}}$ and ET calculations for the Hanford site, and Section 5 provides conclusions.

\section{Calculating potential evapotranspiration and evapotranspiration}

\subsection{Equations for calculations of potential evapotranspiration}

The potential (reference) evapotranspiration $E_{\mathrm{o}}$ is defined as evapotranspiration from a hypothetical $12 \mathrm{~cm}$ grass reference crop under well-watered conditions, with a fixed surface resistance of $70 \mathrm{~s} \mathrm{~m}^{-1}$ and an albedo of 0.23 (Allen et al., 1998). Note that this subsection includes a general description of equations used for calculations of potential evapotranspiration; it does not provide an analysis of the various advantages and disadvantages in applying these equations, which are given in other publications (for example, Allen et al., 1998; Allen \& Pruitt, 1986; Batchelor, 1984; Maulé et al., 2006; Sumner \& Jacobs, 2005; Walter et al., 2002).

The two forms of Baier-Robertson equations (Baier, 1971; Baier \& Robertson, 1965) are given by:

$$
\begin{gathered}
E_{\mathrm{o}}=0.157 T_{\max }+0.158\left(T_{\max }-T_{\min }\right)+0.109 R_{\mathrm{a}}-5.39 \\
E_{\mathrm{o}}=-0.0039 T_{\max }+0.1844\left(T_{\max }-T_{\min }\right)+0.1136 R_{\mathrm{a}}+2.811\left(e_{s}-e_{a}\right)-4.0
\end{gathered}
$$

where $E_{\mathrm{o}}=$ daily evapotranspiration $\left(\mathrm{mm} \mathrm{day}^{-1}\right) ; T_{\max }=$ the maximum daily air temperature, ${ }^{\circ} \mathrm{C} ; T_{\min }=$ minimum temperature, ${ }^{\circ} \mathrm{C} ; R_{a}=$ extraterrestrial radiation $\left(\mathrm{MJ} \mathrm{m}^{-2}\right.$ day $^{-1}$ ) (ASCE $2005), e_{s}=$ saturation vapor pressure $(\mathrm{kPa})$, and $e_{a}=$ mean actual vapor pressure $(\mathrm{kPa})$. Equation (1) takes into account the effect of temperature, and Equation (2) takes into account the effects of temperature and relative humidity.

The Blaney-Criddle equation (Allen \& Pruitt, 1986) is used to calculate evapotranspiration for a reference crop, which is assumed to be actively growing green grass of $8-15 \mathrm{~cm}$ height:

$$
E_{o}=p\left(0.46 \cdot T_{\text {mean }}+8\right)
$$

where $E_{o}$ is the reference (monthly averaged) evapotranspiration $\left(\mathrm{mm} \mathrm{day}^{-1}\right), T_{\text {mean }}$ is the mean daily temperature $\left({ }^{\circ} \mathrm{C}\right)$ given as $T_{\text {mean }}=\left(T_{\max }+T_{\min }\right) / 2$, and $p$ is the mean daily percentage of annual daytime hours.

The Caprio (1974) equation for calculating the potential evapotranspiration is given by

$$
E_{\mathrm{o}}=6.1 \cdot 10^{-6} R_{\mathrm{s}}\left[\left(1.8 \cdot T_{\text {mean }}\right)+1.0\right]
$$

where $E_{\mathrm{o}}=$ mean daily potential evapotranspiration $\left(\mathrm{mm}\right.$ day $\left.{ }^{-1}\right) ; R_{\mathrm{s}}=$ daily global (total) solar radiation $\left(\mathrm{kJ} \mathrm{m}^{-2} \mathrm{day}^{-1}\right)$; and $T_{\text {mean }}=$ mean daily air temperature $\left({ }^{\circ} \mathrm{C}\right)$. 
The Hansen (1984) equation is given by:

$$
E_{\mathrm{o}}=0.7 \Delta /(\Delta+\gamma) \cdot R_{\mathrm{i}} / \lambda
$$

where $\Delta=$ slope of the saturation vapor pressure vs. temperature curve, $\gamma=$ psychrometric constant, $R_{\mathrm{i}}=$ global radiation, and $\lambda=$ latent heat of water vaporization.

The Hargreaves equation (Hargreaves \& Samani, 1985) is given by

$$
E_{\mathrm{o}}=0.0023\left(T_{\text {mean }}+17.8\right)\left(T_{\max }-T_{\min }\right)^{0.5} R_{\mathrm{a}}
$$

where both $E_{\mathrm{o}}$ and $R_{\mathrm{a}}$ (extraterrestrial radiation) are in millimeters per day-1 (mm day ${ }^{-1}$ ). The Jensen and Haise (1963) equation is given by

$$
E_{\mathrm{o}}=R_{\mathrm{s}} / 2450\left[\left(0.025 T_{\text {mean }}\right)+0.08\right]
$$

where $E_{\mathrm{o}}=$ monthly mean of daily potential evapotranspiration $\left(\mathrm{mm} \mathrm{day}^{-1}\right) ; R_{\mathrm{s}}=$ monthly mean of daily global (total) solar radiation $\left(\mathrm{kJ} \mathrm{m}^{-2}\right.$ day-1); and $T_{\text {mean }}=$ monthly mean temperature.

The Linacre (1977) equation is given by:

$$
E_{\mathrm{o}}=\left[500 T_{\mathrm{m}} /(100-L)+15(T-T d)\right] /(80-T)
$$

where $E_{\mathrm{o}}$ is in $\mathrm{mm}$ day- ${ }^{-1}, T_{\mathrm{m}}=$ temperature adjusted for elevation, $T_{\mathrm{m}}=T+0.006 \mathrm{~h}\left({ }^{\circ} \mathrm{C}\right), h=$ elevation $(\mathrm{m}), T_{\mathrm{d}}=$ dew point temperature $\left({ }^{\circ} \mathrm{C}\right)$, and $L=$ latitude $\left({ }^{\circ}\right)$.

The Makkink (1957) model is given by

$$
E_{\mathrm{o}}=0.61 \Delta /(\Delta+\gamma) R_{\mathrm{s}} / 2.45-0.12
$$

where $R_{\mathrm{s}}=$ solar radiation $\left(\mathrm{MJ} \mathrm{m}^{-2}\right.$ day- $\left.^{-1}\right)$, and $\Delta$ and $\gamma$ are the parameters defined above. The Penman (1963) equation is given by

$$
E_{\mathrm{o}}=m R_{\mathrm{n}}+\gamma 6.43\left(1+0.536 u_{2}\right) \delta e / \lambda_{v}(m+\gamma)
$$

where $\Delta=$ slope of the saturation vapor pressure curve $\left(\mathrm{kPa} \mathrm{K}^{-1}\right), R_{\mathrm{n}}=$ net irradiance $\left(\mathrm{MJ} \mathrm{m}^{-2}\right.$ day- $\left.^{-1}\right), \rho_{\mathrm{a}}=$ density of air $\left(\mathrm{kg} \mathrm{m}^{-3}\right), c_{\mathrm{p}}=$ heat capacity of air $\left(\mathrm{J} \mathrm{kg}^{-1} \mathrm{~K}^{-1}\right), \delta e=$ vapor pressure deficit $(\mathrm{Pa}), \lambda_{v}=$ latent heat of vaporization $\left(\mathrm{J} \mathrm{kg}^{-1}\right), \gamma=$ psychrometric constant $\left(\mathrm{Pa} \mathrm{K}^{-1}\right)$, and $E_{\mathrm{o}}$ is in units of $\mathrm{kg} /\left(\mathrm{m}^{2} \mathrm{~s}\right)$.

The general form of the Penman-Monteith equation (Allen et al., 1998) is given by

$$
E_{\mathrm{o}}=\left[0.408 \Delta\left(R_{\mathrm{n}}-G\right)+C_{\mathrm{n}} \gamma /(T+273) u_{2}\left(e_{\mathrm{s}}-e_{\mathrm{a}}\right)\right] /\left[\Delta+\gamma\left(1+C_{\mathrm{d}} u_{2}\right)\right]
$$

where $E_{\mathrm{o}}$ is the standardized reference crop evapotranspiration (in $\mathrm{mm} \mathrm{day}^{-1}$ ) for a short $\left(0.12 \mathrm{~m}\right.$, with values $C_{n}=900$ and $\left.C_{d}=0.34\right)$ reference crop or a tall $\left(0.5 \mathrm{~m}\right.$, with values $C_{n}=1600$ and $\left.C_{\mathrm{d}}=0.38\right)$ reference crop, $R_{\mathrm{n}}=$ net radiation at the crop surface $\left(\mathrm{MJ} \mathrm{m}^{-2}\right.$ day-1 $\left.^{-1}\right), G=$ soil heat flux density $\left(\mathrm{MJ} \mathrm{m}^{-2}\right.$ day $\left.^{-1}\right), T=$ air temperature at $2 \mathrm{~m}$ height $\left({ }^{\circ} \mathrm{C}\right), u_{2}=$ wind speed at 2 $\mathrm{m}$ height $\left(\mathrm{m} \mathrm{s}^{-1}\right), e_{\mathrm{s}}=$ saturation vapor pressure $(\mathrm{kPa}), e_{\mathrm{a}}=$ actual vapor pressure $(\mathrm{kPa}),\left(e_{\mathrm{s}}-\right.$ $\left.e_{\mathrm{a}}\right)=$ saturation vapor pressure deficit $(\mathrm{kPa}), \Delta=$ slope of the vapor pressure curve $\left(\mathrm{kPa}^{\circ} \mathrm{C}^{-1}\right)$, and $\gamma=$ psychrometric constant $\left(\mathrm{kPa}^{\circ} \mathrm{C}^{-1}\right)$.

The Priestley-Taylor (1972) equation is given by

$$
E_{\mathrm{o}}=\alpha 1 / \lambda \Delta\left(R_{\mathrm{n}}-G\right) /(\Delta+\gamma)
$$


where $\lambda=$ latent heat of vaporization $(\mathrm{MJ} \mathrm{kg}-1), R_{\mathrm{n}}=$ net radiation $\left(\mathrm{MJ} \mathrm{m}^{-2}\right.$ day-1$\left.^{-1}\right), \mathrm{G}=$ soil heat flux (MJ m${ }^{-2}$ day $\left.^{-1}\right), \Delta=$ slope of the saturation vapor pressure-temperature relationship $\left(\mathrm{kPa}{ }^{\circ} \mathrm{C}-1\right), \gamma=$ psychrometric constant $\left(\mathrm{kPa}^{\circ} \mathrm{C}-1\right)$, and $\alpha=1.26$. Eichinger et al. (1996) showed that $\alpha=1.26$ is practically constant for all typically observed atmospheric conditions and relatively insensitive to small changes in atmospheric parameters. (On the other hand, Sumner and Jacobs [2005] showed that $\alpha$ is a function of the green-leaf area index [LAI] and solar radiation.)

The Thornthwaite (1948) equation is given by

$$
E_{\mathrm{o}}=1.6(L / 12)(\mathrm{N} / 30)\left(10 T_{\text {mean (i) }} / I\right)^{\alpha}
$$

where $E_{\mathrm{o}}$ is the estimated potential evapotranspiration $(\mathrm{cm} / \mathrm{month}), T_{\text {mean (i) }}=$ average monthly $(i)$ temperature $\left({ }^{\circ} \mathrm{C}\right)$; if $T_{\text {mean }(i)}<0, E \mathrm{o}=0$ of the month (i) being calculated, $N=$ number of days in the month, $L=$ average day length (hours) of the month being calculated, and $I=$ heat index given by

$$
I=\sum_{i=1}^{12}\left(\frac{T_{\text {mean }(i)}}{5}\right)^{1.514}
$$

and $\alpha=\left(6.75 \cdot 10^{-7}\right) I^{3}-\left(7.71 \cdot 10^{-5}\right) I^{2}+\left(1.792 \cdot 10^{-2}\right) I+0.49239$

The Turc (1963) equation is given by

$$
E_{\mathrm{o}}=\left(0.0239 \cdot R_{\mathrm{s}}+50\right)\left[0.4 / 30 \cdot T_{\text {mean }} /\left(T_{\text {mean }}+15.0\right)\right]
$$

where $E_{o}=$ mean daily potential evapotranspiration (mm/day); $R_{s}=$ daily global (total) solar radiation $\left(\mathrm{kJ} / \mathrm{m}^{2} /\right.$ day $) ; T_{\text {mean }}=$ mean daily air temperature $\left({ }^{\circ} \mathrm{C}\right)$.

\subsection{Modified Budyko's equation for evaluating evapotranspiration}

For regional-scale, long-term water-balance calculations within arid and semi-arid areas, we can reasonably assume that (1) soil water storage does not change, (2) lateral water motion within the shallow subsurface is negligible, (3) the surface-water runoff and runon for regional-scale calculations simply cancel each other out, and (4) ET is determined as a function of the aridity index, $\phi: E T=f(\phi)$, where $\phi=E_{\mathrm{o}} / P$, which is the ratio of potential evapotranspiration, $E_{\mathrm{o}}$, to precipitation, $P$ (Arora 2002).

Budyko's (1974) empirical formula for the relationship between the ratio of ET/P and the aridity index was developed using the data from a number of catchments around the world, and is given by:

$$
E T / P=\{\phi \tanh (1 / \phi)[1-\exp (-\phi)]\}^{0.5}
$$

Equation (1) can also be given as a simple exponential expression (Faybishenko, 2010):

$$
E T / P=a[1-\exp (-b \phi)]
$$

with coefficients $a=0.9946$ and $b=1.1493$. The correlation coefficient between the calculations using (15) and (16) is $R=0.999$. Application of the modified Budyko's equation, given by an exponential function (2) with the $\phi$ value in single term, will simplify further calculations of ET. 


\section{Types of uncertainties in calculating evapotranspiration and simulation approaches}

\subsection{Epistemic and aleatory uncertainties}

The uncertainties involved in predictions of evapotranspiration, as a component of soilwater balance, can generally be categorized into two groups-aleatory and epistemic uncertainties. Aleatory uncertainty arises because of the natural, inherent variability of soil and meteorological parameters, caused by the subsurface heterogeneity and variability of meteorological parameters. If sufficient information is available, probability density functions (PDFs) of input parameters can be used for stochastic simulations to assess aleatory evapotranspiration uncertainty. In the event of a lack of reliable experimental data, fuzzy numbers can be used for fuzzy or fuzzy-probabilistic calculations of the aleatory evapotranspiration uncertainty (Faybishenko 2010).

Epistemic uncertainty arises because of a lack of knowledge or poor understanding, ambiguous, conflicting, or insufficient experimental data needed to characterize coupledphysics phenomena and processes, as well as to select or derive appropriate conceptualmathematical models and their parameters. This type of uncertainty is also referred to as subjective or reducible uncertainty, because it can be reduced as new information becomes available, and by using various models for uncertainty evaluation. Generally, variability, imprecise measurements, and errors are distinct features of uncertainty; however, they are very difficult, if not impossible, to distinguish (Ferson \& Ginzburg, 1995).

In this chapter the author will consider the effect of aleatory uncertainty on evapotranspiration calculations by assigning the probability distributions of input meteorological parameters, and the effect of epistemic uncertainty is considered by using different evapotranspiration models.

\subsection{Simulation approaches}

\subsubsection{Probability approach}

A common approach for assessing uncertainty is based on Monte Carlo simulations, using PDFs describing model parameters. Another probability-based approach to the specification of uncertain parameters is based on the application of probability boxes (Ferson, 2002; Ferson et al., 2003). The probability box (p-box) approach is used to impose bounds on a cumulative distribution function (CDF), expressing different sources of uncertainty. This method provides an envelope of distribution functions that bounds all possible dependencies. An uncertain variable $x$ expressed with a probability distribution, as shown in Figure $1 \mathrm{a}$, can be represented as a variable that is bounded by a p-box $[\bar{F}, \underline{F}]$, with the right curve $\underline{F}(x)$ bounding the higher values of $x$ and the lower probability of $x$, and the left curve $\bar{F}(x)$ bounding the lower values and the higher probability of $x$. With better or sufficiently abundant empirical information, the p-box bounds are usually narrower, and the results of predictions come close to a PDF from traditional probability theory.

\subsubsection{Possibility approach}

In the event of imprecise, vague, inconsistent, incomplete, or subjective information about models and input parameters, the uncertainty is captured using fuzzy modeling theory, or possibility theory, introduced by Zadeh (1978). For the past 50 years or so, possibility theory has successfully been applied to describe such systems as complex, large-scale engineering systems, social and economic systems, management systems, medical diagnostic processes, human perception, and others. The term fuzziness is, in general, used in possibility theory to 

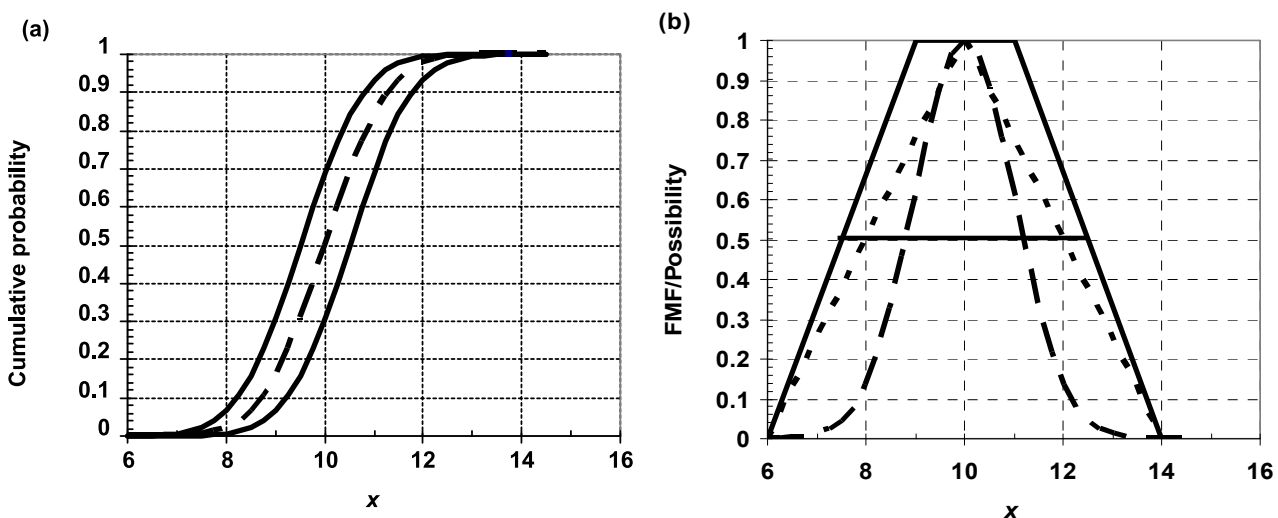

Fig. 1. Graphical illustration of uncertain numbers: (a) Cumulative normal distribution function (dashed line), with mean=10 and standard deviation $\sigma=1$, and a p-box - left bound with mean=9.5 and $\sigma=0.9$, and right bound with mean=10.5 and $\sigma=1.1$; and (b) Fuzzy trapezoidal (solid line) number, plotted using Eq. (17) with $a=6, b=9, c=11$, and $d=14$. Interval $[b, c]=[9,11]$ corresponds to $F M F=1$. Triangular (short dashes) and Gaussian (long dashes) fuzzy numbers are also shown. Figure (b) also shows an $\alpha$-cut $=0.5$ (thick horizontal line) through the trapezoidal fuzzy number (Faybishenko 2010).

describe objects or processes that cannot be given precise definition or precisely measured. Fuzziness identifies a class (set) of objects with nonsharp (i.e., fuzzy) boundaries, which may result from imprecision in the meaning of a concept, model, or measurements used to characterize and model the system. Fuzzification implies replacing a set of crisp (i.e., precise) numbers with a set of fuzzy numbers, using fuzzy membership functions based on the results of measurements and perception-based information (Zadeh 1978). A fuzzy number is a quantity whose value is imprecise, rather than exact (as is the case of a singlevalued number). Any fuzzy number can be thought of as a function whose domain is a specified set of real numbers. Each numerical value in the domain is assigned a specific "grade of membership," with 0 representing the smallest possible grade (full nonmembership), and 1 representing the largest possible grade (full membership). The grade of membership is also called the degree of possibility and is expressed using fuzzy membership functions (FMFs). In other words, a fuzzy number is a fuzzy subset of the domain of real numbers, which is an alternative approach to expressing uncertainty.

Several types of FMFs are commonly used to define fuzzy numbers: triangular, trapezoidal, Gaussian, sigmoid, bell-curve, Pi-, S-, and Z-shaped curves. As an illustration, Figure 1b shows a trapezoidal fuzzy number given by

$$
f(x)=\left\{\begin{array}{l}
0, x \leq a \\
\frac{x-a}{b-a}, a \leq x \leq b \\
1, b \leq x \leq c \\
\frac{d-x}{d-c}, c \leq x \leq d \\
0, d \leq x
\end{array}\right\},
$$


where coefficients $a, b, c$, and $d$ are used to define the shape of the trapezoidal FMF. When $a=b$, the trapezoidal number becomes a triangular fuzzy number.

Figure $1 \mathrm{~b}$ also illustrates one of the most important attributes of fuzzy numbers, which is the notion of an $\alpha$-cut. The $\alpha$-cut interval is a crisp interval, limited by a pair of real numbers. An $\alpha$-cut of 0 of the fuzzy variable represents the widest range of uncertainty of the variable, and an $\alpha$-cut value of 1 represents the narrowest range of uncertainty of the variable.

Possibility theory is generally applicable for evaluating all kinds of uncertainty, regardless of its source or nature. It is based on the application of both hard data and the subjective (perception-based) interpretation of data. Fuzzy approaches provide a distribution characterizing the results of all possible magnitudes, rather than just specifying upper or lower bounds. Fuzzy methods can be combined with calculations of PDFs, interval numbers, or p-boxes, using the RAMAS Risk Calc code (Ferson 2002). In this paper, the RAMAS Risk Calc code is used to assess the following characteristic parameters of the fuzzy numbers and p-boxes:

- Mean-an interval between the means of the lower (left) and upper (right) bounds of the uncertain number $x$.

- Core-the most possible value(s) of the uncertain number $x$, i.e., value(s) with a possibility of one, or for which the probability can be any value between zero and one.

- Iqrange - an interval guaranteed to enclose the interquartile range (with endpoints at the 25th and 75th percentiles) of the underlying distribution.

- Breadth of uncertainty - for fuzzy numbers, given by the area under the membership function; for $p$-boxes, given by the area between the upper and lower bounds. The uncertainty decreases as the breadth of uncertainty decreases.

When fuzzy measures serve as upper bounds on probability measures, one could expect to obtain a conservative (bounding) prediction of system behavior. Therefore, fuzzy calculations may overestimate uncertainty. For example, the application of fuzzy methods is not optimal (i.e., it overestimates uncertainty) when sufficient data are available to construct reliable PDFs needed to perform a Monte Carlo analysis.

In a recent paper (Faybishenko 2010), this author demonstrated the application of the fuzzyprobabilistic method using a hybrid approach, with direct calculations, when some quantities can be represented by fuzzy numbers and other quantities by probability distributions and interval numbers (Kaufmann and Gupta 1985; Ferson 2002; Guyonnet et al. 2003; Cooper et al. 2006). In this paper, the author combines (aggregates) the results of Monte Carlo calculations with multiple $E_{\mathrm{o}}$ models by means of fuzzy numbers and p-boxes, using the RAMAS Risk Calc software (Ferson 2002).

\section{Hanford case study}

\subsection{Input parameters and modeling scenarios for the Hanford Site}

The Hanford Site in Southeastern Washington State is one of the largest environmental cleanup sites in the USA, comprising 1,450 $\mathrm{km}^{2}$ of semiarid desert. Located north of Richland, Washington, the Hanford Site is bordered on the east by the Columbia River and on the south by the Yakima River, which joins the Columbia River near Richland, in the Pasco Basin, one of the structural and topographic basins of the Columbia Plateau. The areal topography is gently rolling and covered with unconsolidated materials, which are sufficiently thick to mask the surface irregularities of the underlying material. Areas adjacent to the Hanford Site are primarily agricultural lands. 
Meteorological parameters used to assign model input parameters were taken from the Hanford Meteorological Station (HMS - see http://hms.pnl.gov/), located at the center of the Hanford Site just outside the northeast corner of the 200 West Area, as well as from publications (DOE, 1996; Hoitink et al., 2002; Neitzel, 1996.) At the Hanford Site, the $E_{\mathrm{o}}$ is estimated to be from 1,400 to 1,611 mm/yr (Ward et al. 2005), and the ET is estimated to be $160 \mathrm{~mm} / \mathrm{yr}$ (Figure 2). A comparison of field estimates with the results of calculations performed in this paper is shown in Section 4.2. Calculations are performed using the temperature and precipitation time-series data representing a period of active soil-water balance (i.e., with no freezing) from March through October for the years 1990-2007. A set of meteorological parameters is summarized in Table 1, which are then used to develop the input PDFs and fuzzy numbers shown in Figure 3.

Several modeling scenarios were developed (Table 2) to assess how the application of different models for input parameters affects the uncertainty of $E_{\mathrm{o}}$ and $E T$ calculations. For the sake of simulation simplicity, the input parameters are assumed to be independent variables. Scenarios 0 to 8, described in detail in Faybishenko (2010), are based on the application of a single Penman model for $E_{\mathrm{o}}$ calculations, with annual average values of input parameters. Scenario 0 was modeled using input PDFs by means of Monte Carlo simulations, using RiskAMP Monte Carlo Add-In Library version 2.10 for Excel. Scenarios 1 through 8 were simulated by means of the RAMAS Risk Calc code. Scenario 1 was simulated using input PDFs, and the results are given as p-box numbers. Scenarios 2 through 6 were simulated applying both PDFs and fuzzy number inputs, corresponding to $\alpha$-cuts from 0 to 1 ). Scenarios 7 and 8 were simulated using only fuzzy numbers. The calculation results of Scenarios 0 through 8 are compared in this chapter with newly calculated Scenarios 9 and 10, which are based on Monte Carlo calculations by means of all $E_{\mathrm{o}}$ models, described in Section 2, and then bounding the resulting PDFs by a trapezoidal fuzzy number (Scenario 9) and the p-box (Scenario 10).

\begin{tabular}{|c|c|c|c|c|c|c|c|c|c|c|}
\hline \multirow[t]{2}{*}{$\begin{array}{l}\text { Type } \\
\text { of data }\end{array}$} & \multirow{2}{*}{\multicolumn{2}{|c|}{ Parameters }} & \multirow[t]{2}{*}{$\begin{array}{c}\text { Wind } \\
\text { speed } \\
(\mathrm{km} / \mathrm{hr})\end{array}$} & \multicolumn{2}{|c|}{$\begin{array}{l}\text { Relative } \\
\text { humidity } \\
(\%)\end{array}$} & \multirow[t]{2}{*}{ Albedo } & \multirow[t]{2}{*}{$\begin{array}{c}\text { Solar } \\
\text { radiation } \\
\text { (Ly/day) }\end{array}$} & \multirow{2}{*}{$\begin{array}{c}\text { Annual } \\
\text { precipi- } \\
\text { tation } \\
(\mathrm{mm} / \mathrm{yr})\end{array}$} & \multicolumn{2}{|c|}{$\begin{array}{c}\text { Temperature } \\
\left({ }^{\circ} \mathrm{C}\right)\end{array}$} \\
\hline & & & & $\operatorname{Max}$ & Min & & & & Max & Min \\
\hline \multirow[t]{2}{*}{ PDFs } & \multicolumn{2}{|c|}{ Mean } & 15.07 & 80.2 & 33.3 & 0.21 & 332.55 & 185 & 33.41 & 2.87 \\
\hline & \multicolumn{2}{|c|}{$\begin{array}{c}\text { Standard } \\
\text { Deviation }\end{array}$} & 0.92 & 4.01 & 1.66 & 0.021 & 16.63 & 55.62 & 1.08 & 1.11 \\
\hline \multirow{4}{*}{$\begin{array}{l}\text { Trape- } \\
\text { zoidal } \\
\text { FMFs }\end{array}$} & \multirow[t]{2}{*}{$\alpha=0$} & Min & 12.31 & 68.17 & 28.29 & 0.15 & 282.66 & 46.0 & 30.17 & 0.0 \\
\hline & & $\operatorname{Max}$ & 17.84 & 92.23 & 38.31 & 0.27 & 382.44 & 324.1 & 36.65 & 6.17 \\
\hline & \multirow[t]{2}{*}{$\alpha=1$} & Min & 14.61 & 78.2 & 32.47 & 0.22 & 324.24 & 157.2 & 32.87 & 2.32 \\
\hline & & $\operatorname{Max}$ & 15.53 & 82.2 & 34.14 & 0.27 & 382.44 & 212.8 & 33.95 & 3.42 \\
\hline
\end{tabular}

Table 1. Meteorological parameters from the Hanford Meteorological Station used for $E_{\mathrm{o}}$ calculations for all scenarios (the data sources are given in the text). 


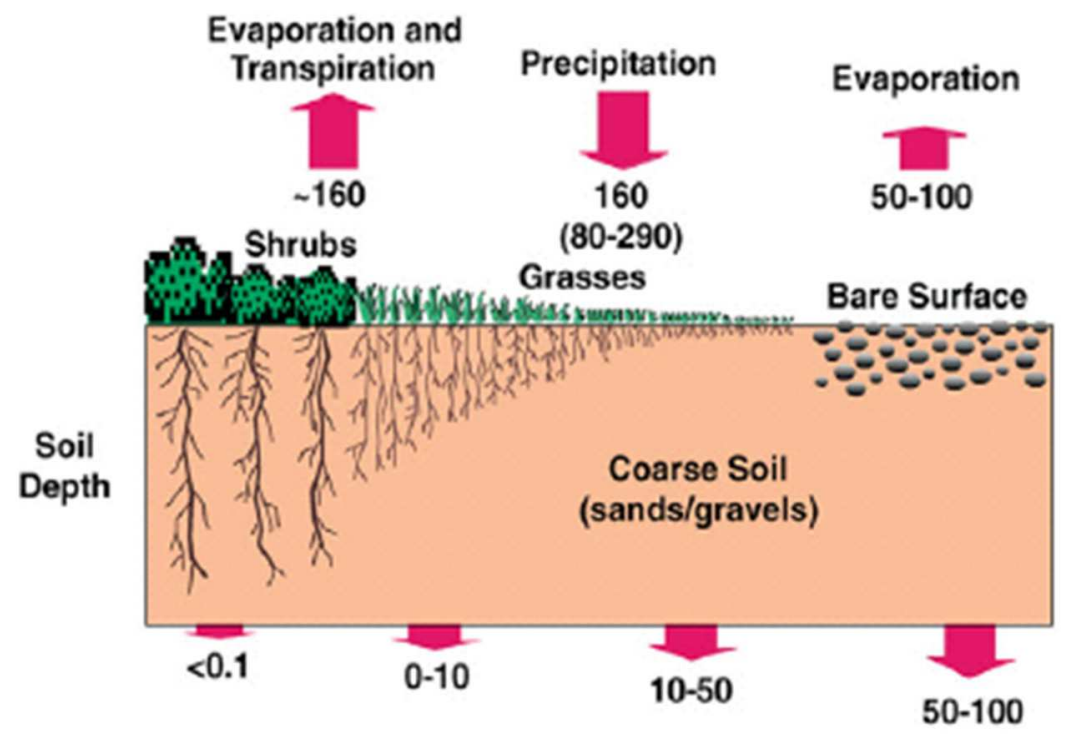

Estimated Range of Recharge Rates

Fig. 2. Estimated water balance ET and recharge/infiltration at the Hanford site (Gee et al, 2007).

\begin{tabular}{|c|c|c|c|c|c|c|c|}
\hline \multirow[b]{2}{*}{ 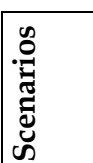 } & \multicolumn{6}{|c|}{ Input parameters } & \multirow{2}{*}{$\begin{array}{c}\text { Output } \\
\text { para- } \\
\text { meters }\end{array}$} \\
\hline & $\begin{array}{l}\text { Wind } \\
\text { speed }\end{array}$ & Humidity & Albedo & $\begin{array}{c}\text { Solar } \\
\text { radiation }\end{array}$ & $\begin{array}{c}\text { Precipi- } \\
\text { tation }\end{array}$ & $\begin{array}{l}\text { Tempe- } \\
\text { rature }\end{array}$ & \\
\hline 0 & PDF & PDF & PDF & PDF & PDF & PDF & PDF \\
\hline 1 & PDF & PDF & PDF & PDF & PDF & PDF & p-box \\
\hline 2 & Fuzzy & PDF & PDF & PDF & PDF & PDF & Hybrid \\
\hline 3 & Fuzzy & Fuzzy & PDF & PDF & PDF & PDF & Hybrid \\
\hline 4 & Fuzzy & Fuzzy & Fuzzy & PDF & PDF & PDF & Hybrid \\
\hline 5 & Fuzzy & Fuzzy & Fuzzy & Fuzzy & PDF & PDF & Hybrid \\
\hline 6 & Fuzzy & Fuzzy & Fuzzy & Fuzzy & Fuzzy & PDF & Hybrid \\
\hline 71) & Fuzzy & Fuzzy & Fuzzy & Fuzzy & Fuzzy & Fuzzy & Fuzzy \\
\hline 82) & Fuzzy & Fuzzy & Fuzzy & Fuzzy & Fuzzy & Fuzzy & Fuzzy \\
\hline 93) & PDF & PDF & PDF & PDF & PDF & PDF & Fuzzy \\
\hline 103) & PDF & PDF & PDF & PDF & PDF & PDF & p-box \\
\hline
\end{tabular}

Notes:

1) In Scenario 7, all FMFs are trapezoidal.

2) In Scenario 8, all FMFs are triangular: the mean values of parameters, which are given in Table 1, are used for $\alpha=1$; and the minimum and maximum values of parameters, given in Table 1 for trapezoidal FMFs (Scenario 7), are also used for $\alpha=0$ of triangular FMFs in Scenario 8.

3) In Scenarios 9 and 10, input parameters are monthly averaged.

Table 2. Scenarios of input and output parameters used for water-balance calculations (Scenarios 0, and 1-8 are from Faybishenko, 2010). 


\subsection{Results and comparison with field data}

\subsubsection{Potential evapotranspiration $\left(E_{\mathrm{o}}\right)$}

Figure $4 \mathrm{a}$ shows cumulative distributions of $E_{\mathrm{o}}$ from different models, along with an aggregated p-box, and Figure $4 \mathrm{~b}$ shows the corresponding FMFs (calculated as normalized PDFs) of $E_{\mathrm{o}}$ from different models, along with an aggregated trapezoidal fuzzy $E_{\mathrm{o}}$. These figures illustrate that the Baier-Robertson (Eq. 1), Blaney-Criddle (Eq. 3), Hargreaves (Eq. 6), Penman (Eq. 10), Penman-Monteith (Eq. 11) (for tall plants), and Priestly-Taylor (Eq. 12) models provide the best match with field data, while the Makkink (Eq. 9) and Thornthwaite (Eq. 13) models significantly underestimate the $E_{\mathrm{o}}$, and the Linacre (Eq. 8) and BaierRobertson (Eq. 2) models greatly overestimate $E_{\mathrm{o}}$.
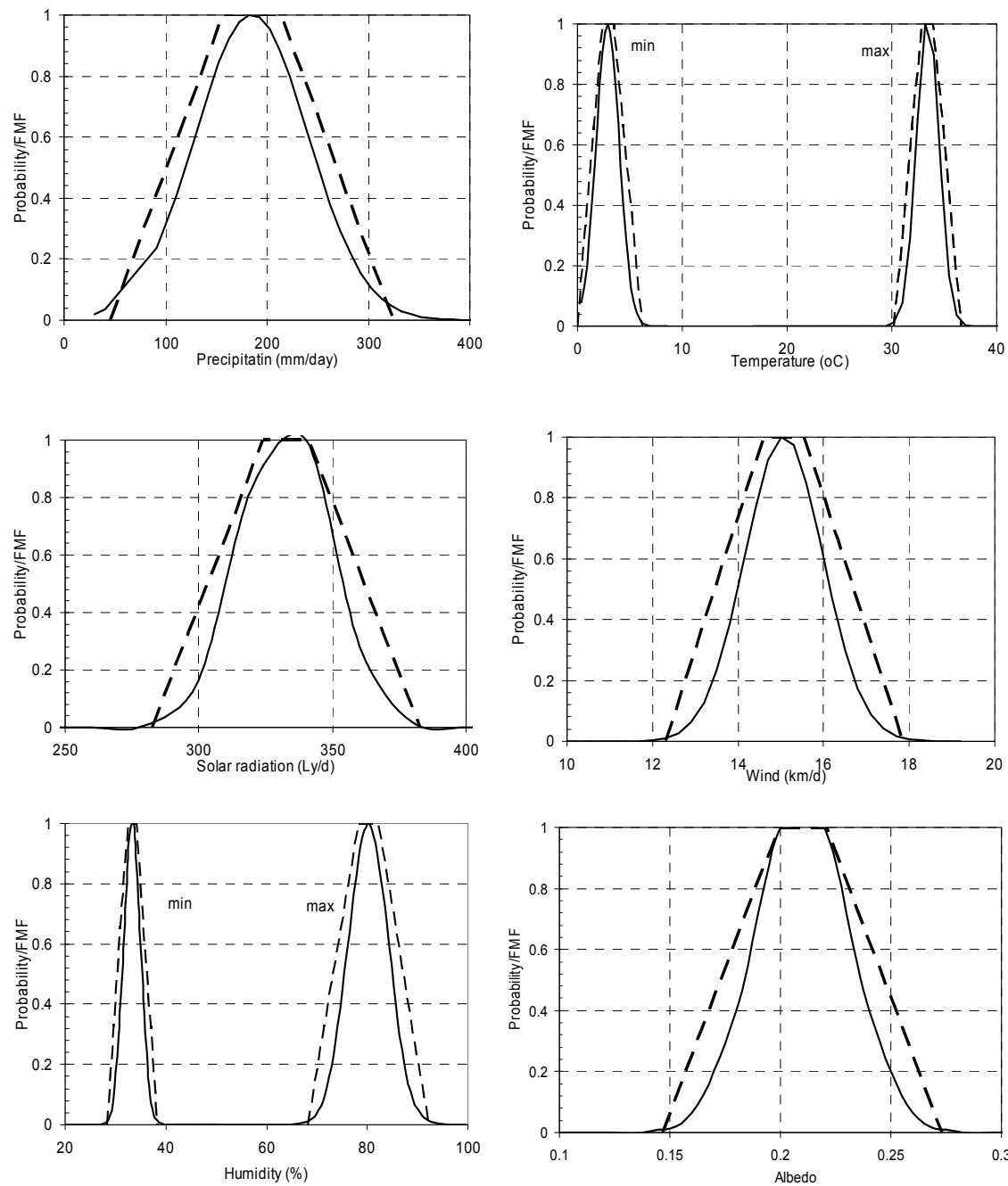

Fig. 3. Input PDFs (solid lines) and fuzzy numbers (dashed lines) used for calculations (Faybishenko, 2010). 
Figure 5a demonstrates that the $E_{\mathrm{o}}$ mean from Monte Carlo simulations is within the mean ranges from the p-box (Scenario 1) and fuzzy-probabilistic scenarios (Scenarios 2-6). It also corresponds to a midcore of the fuzzy scenario with trapezoidal FMFs (Scenario 7), the core of the fuzzy scenario with triangular FMFs (Scenario 8), and the centroid values of the fuzzy $E_{\mathrm{o}}$ of Scenario 9, as well as a p-box of Scenario 10.
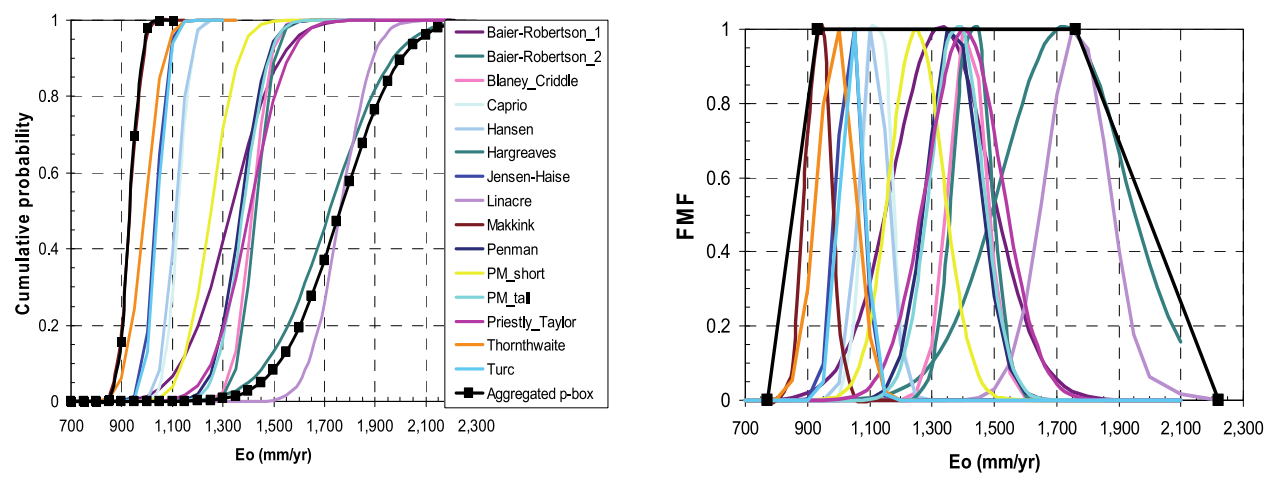

Fig. 4. (a) Cumulative probability of potential evapotranspiration calculated using different $E_{\mathrm{o}}$ formulae; an aggregated p-box, which is shown by a black line with solid squares: normal distribution with the left/minimum curve - mean=933, var=1070, and the right / $\max$ curve - mean=1763, var=35755; and (b) corresponding fuzzy numbers (calculated from normalized PDFs); an aggregated trapezoidal fuzzy number is shown by a black line-Eq. (17) with $a=772, b=933, c=1763$, and $d=2222$. (all numbers of $E_{\mathrm{o}}$ are in $\mathrm{mm} / \mathrm{yr}$ )

The range of means from the p-box and fuzzy-probabilistic calculations for $\alpha=1$ is practically the same, indicating that including fuzziness within the input parameters does not change the range of most possible $E_{\mathrm{o}}$ values. Figure 5a shows that the core uncertainty of the trapezoidal FMFs (Scenario 7) is the same as the uncertainty of means for fuzzy-probabilistic calculations for $\alpha=1$. Obviously, the output uncertainty decreases for the input triangular FMFs (Scenario 8), because these FMFs resemble more tightly the PDFs used in other scenarios. Figure 5a also illustrates that a relatively narrow range of field estimates of $E_{0}-$ from 1,400 to 1,611 mm/yr for the Hanford site (Ward 2005) - is well within the calculated uncertainty of $E_{\mathrm{o}}$ values. Note from Figure $5 \mathrm{a}$ that the uncertainty ranges from p-box, hybrid, and fuzzy calculations significantly exceed those from Monte Carlo simulations for a single Penman model, but are practically the same as those from calculations using multiple $E_{\mathrm{o}}$ models.

Characteristic parameters (Figures 5a) and the breadth of uncertainty (Figure 6a) of $E_{\mathrm{o}}$ calculated from multiple models-Scenarios 9 and 10-are in a good agreement with field measurements and other calculation scenarios.

\subsubsection{Evapotranspiration ( $E T)$}

Figure $5 \mathrm{~b}$ shows that the mean ET of $\sim 184 \mathrm{~mm} / \mathrm{yr}$ from Monte Carlo simulations (Scenario 0) is practically the same as the ET means for Scenarios 1 through 5 and the core value for Scenario 8. The greater ET uncertainty for Scenario 6 (precipitation is simulated using a fuzzy number) can be explained by the relatively large precipitation range for $\alpha=0$-from 46 to $324 \mathrm{~mm} / \mathrm{yr}$. At the same time, the means of ET values for $\alpha=1$ range 
within relatively narrow limits, as the precipitation for $\alpha=1$ changes from 157.2 to 212.8 $\mathrm{mm} / \mathrm{yr}$ (see Table 1).

The breadth of uncertainty of ET (Figure 6b) is practically the same for Scenarios 1 through 5 , increase for Scenarios 6, 7, and 8 in the account of calculations using a fuzzy precipitation, and then decrease for Scenarios 9 and 10 using multiple $E_{o}$ models. A smaller range of ET uncertainty calculated using multiple $E_{\mathrm{o}}$ models can be explained by the fact that the Budyko curve asymptotically reaches the limit of $E T / P=1$ for high values of the aridity index, which are typical for the semi-arid climatic conditions of the Hanford site.

(a)

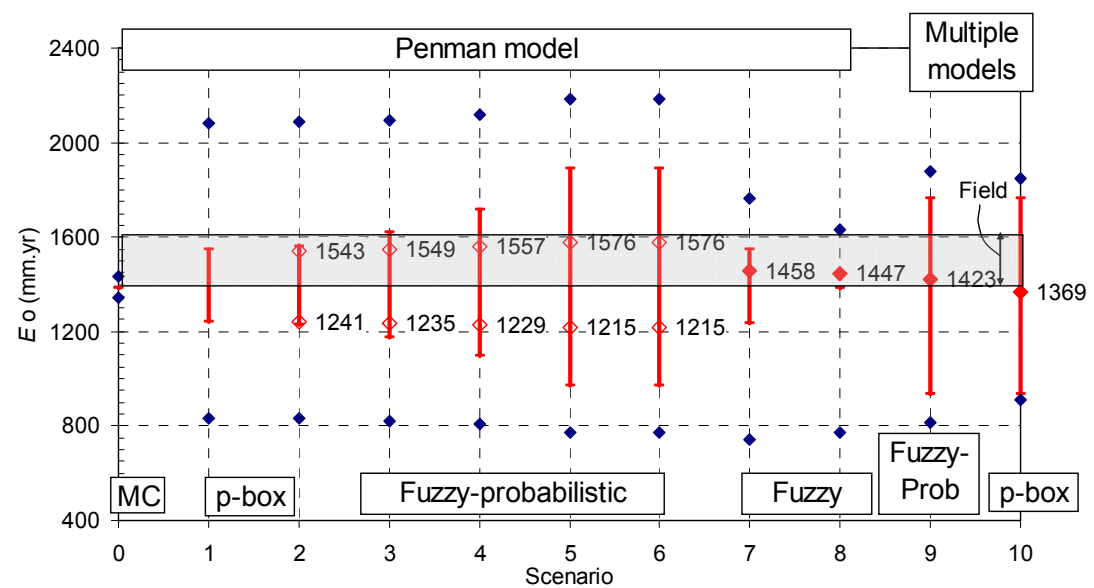

(b)

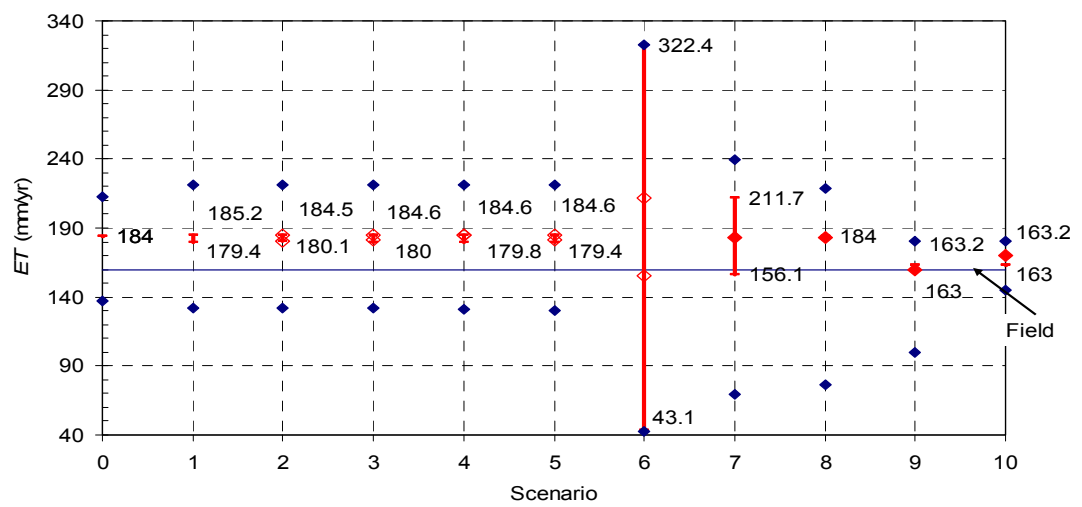

Fig. 5. Results of calculations of $E_{\mathrm{o}}(\mathrm{a})$ and $E T(\mathrm{~b})$ and comparison with field measurements. Red vertical lines are the mean intervals (Scenarios 1-6, and 10) and core intervals (Scenarios 7,8 , and 9), the blue diamonds indicate the interquartile ranges with endpoints at the $25^{\text {th }}$ and $75^{\text {th }}$ percentiles of the underlying distribution. Red open diamonds for Scenarios 2-6 indicate the mean intervals for the hybrid level=10 (Faybishenko 2010), and red solid diamonds for Scenarios 7-10 indicate centroid values. The height of a shaded area in figure $a$ indicates the range of $E_{\mathrm{o}}$ from field measurements. (Results of calculations of Scenarios 0-8 are from Faybishenko, 2010.) 
The calculated means for Scenarios 0, 1-5, and 8 exceed the field estimates of ET of 160 $\mathrm{mm} / \mathrm{yr}$ (Gee et al., 1992; 2007) by 22 to $24 \mathrm{~mm} / \mathrm{yr}$. This difference can be explained by Gee et al. using a lower value of annual precipitation $(160 \mathrm{~mm} / \mathrm{yr}$ for the period prior to 1990) in their calculations, while our calculations are based on using a greater mean annual precipitation ( $185 \mathrm{~mm} / \mathrm{yr}$ ), averaged for the years from 1990 to 2007 . The field-based data are within the ET uncertainty range for Scenarios 6 and 7, since the precipitation range is wider for these scenarios. Calculations using multiple $E_{0}$ models generated the ET values (Scenarios 9 and 10), which are practically the same as those from field measurements.
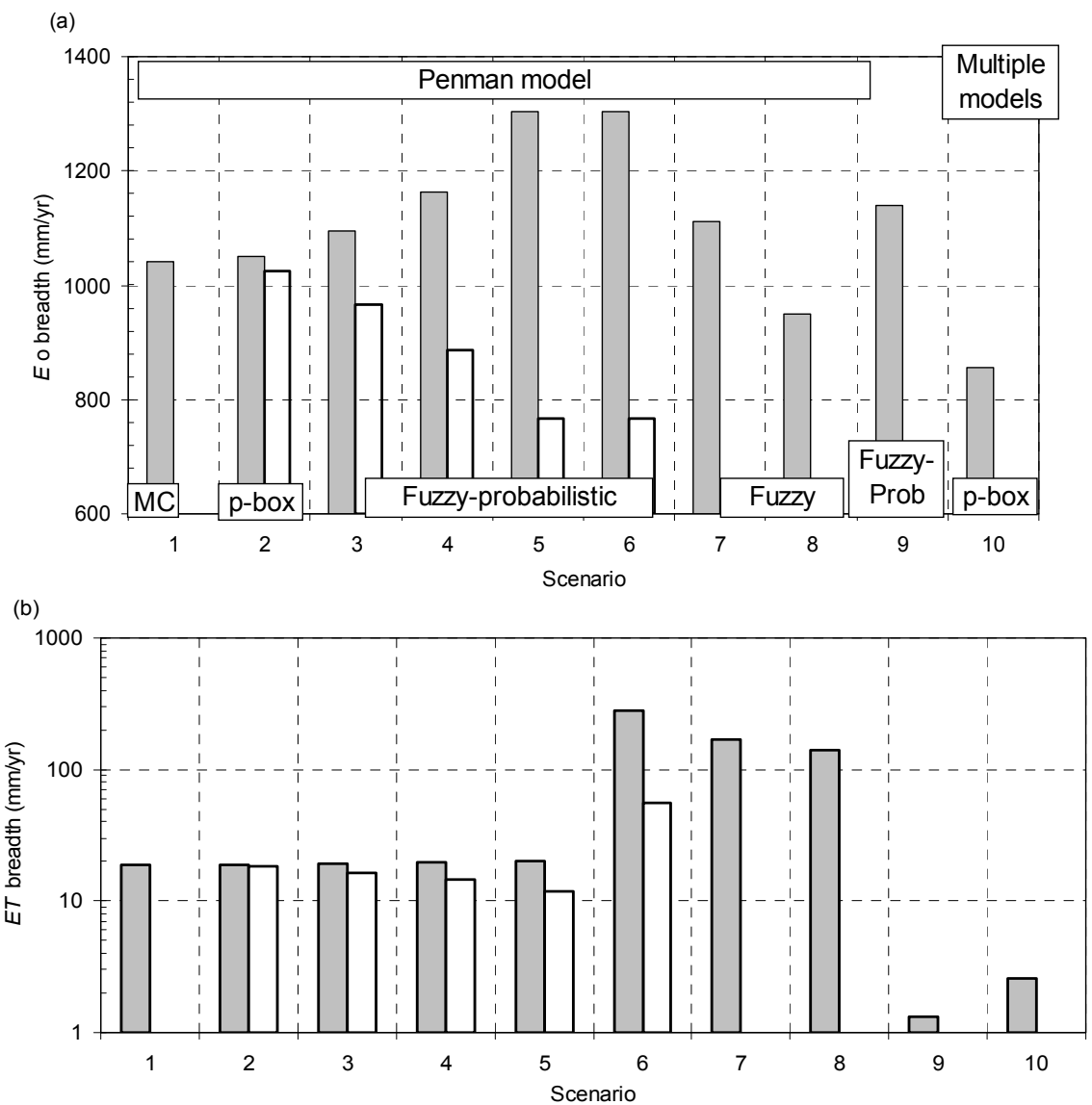

Fig. 6. Breadth of uncertainty of $E_{\mathrm{o}}$ and ET. For Scenarios 2-6, grey and white bars indicate the maximum and minimum uncertainty, correspondingly. (Results of calculations of Scenarios 0-8 are from Faybishenko, 2010.)

\section{Conclusions}

The objectives of this chapter are to illustrate the application of a fuzzy-probabilistic approach for predictions of $E_{\mathrm{o}}$ and $E T$, and to compare the results of calculations with those 
from field measurements at the Hanford site. Using historical monthly averaged data from the Hanford Meteorological Station, this author employed Monte-Carlo simulations to assess the frequency distribution and statistics of input parameters for these models, which are then used as input into probabilistic simulations. The effect of aleatory uncertainty on calculations of evapotranspiration is assessed by assigning the probability distributions of input meteorological parameters, and the combined effect of aleatory and epistemic (model) uncertainty is then expressed by means of aggregating the results of calculations using a pbox and fuzzy numbers. To illustrate the application of these approaches, the potential evapotranspiration is calculated using the Bair-Robertson, Blaney-Criddle, Caprio, Hargreaves-Samani, Hamon, Jensen-Haise, Linacre, Makkink, Priestly-Taylor, Penman, Penman-Monteith, Thornthwaite, and Turc models, and evapotranspiration is then determined based on the modified Budyko (1974) model. Probabilistic and fuzzyprobabilistic calculations using multiple $E_{\mathrm{o}}$ models generate the $E_{\mathrm{o}}$ and $E T$ results, which are well within the range of field measurements and the application of a single Penman model. The Baier-Robertson, Blaney-Criddle, Hargreaves, Penman, Penman-Monteith, and PriestlyTaylor models provide the best match with field data.

\section{Acknowledgment}

This work was partially supported by the Director, Office of Science, Office of Biological and Environmental Remediation Sciences of the U.S. Department of Energy, and the DOE EM-32 Office of Soil and Groundwater Remediation (ASCEM project) under Contract No. DEAC02-05CH11231 to Lawrence Berkeley National Laboratory.

\section{References}

Allen, R.G. \& Pruitt, W.O. (1986), Rational Use of the FAO Blaney-Criddle Formula, Journal of Irrigation and Drainage Engineering, Vol. 112, No. 2, pp. 139-155, doi 10.1061/(ASCE)0733-9437(1986)112:2(139)

Allen, R.G.; Pereira L.S.; Raes, D. \& Smith, M. (1998). Crop evapotranspiration - Guidelines for computing crop water requirements - FAO Irrigation and drainage paper 56.

Arora V.K. (2002). The use of the aridity index to assess climate change effect on annual runoff, J. of Hydrology, Vol. 265, pp. 164-177.

ASCE (2005). The ASCE Standardized Reference Evapotranspiration Equation. Edited by R. G. Allen, I.A. Walter, R.; Elliott, T. Howell, D. Itenfisu, and M. Jensen. New York, NY: American Society of Civil Engineers.

Baier, W. \& Robertson, G.W. 1965. Estimation of latent evaporation from simple weather observations. Can. J. Soil Sci. 45, pp. 276-284.

Baier, W. (1971). Evaluation of latent evaporation estimates and their conversion to potential evaporation. Can. J. of Plant Sciences 51, pp. 255-266.

Budyko, M.I. (1974).Climate and Life, Academic, San Diego, Calif., 508 pp.

Buttafuoco, G.; Caloiero, T.; \& Coscarelli, R. (2010). Spatial uncertainty assessment in modelling reference evapotranspiration at regional scale, Hydrol. Earth Syst. Sci., 14, pp. 2319-2327, doi:10.5194/hess-14-2319-2010, 2010. 
Caprio, J.M. (1974). The Solar Thermal Unit Concept in Problems Related to Plant Development and Potential Evapotranspiration. In: H. Lieth (Editor), Phenology and Seasonality Modeling. Ecological Studies. Springer Verlag, New York, pp. 353-364.

Chang N-B (2005). Sustainable water resources management under uncertainty, Stochast Environ Res and Risk Assess, 19, pp. 97-98.

Cooper J.A.; Ferson, S.; \& Ginzburg, L. (2006). Hybrid processing of stochastic and subjective uncertainty data, Risk Analysis, Vol. 16, No. 6, pp. 785-791.

DOE (1996). Final Environmental Impact Statement for the Tank Waste Remediation System, Hanford Site, Richland, Washington, DOE/EIS-0189. Available from http://www.globalsecurity.org/wmd/library/report/enviro/eis-0189/app_i_3.htm

Dubois, D. \& Prade, H. (1994). Possibility theory and data fusion in poorly informed environments. Control Engineering Practice 2(5), pp. 811-823.

Eichinger W.E.; Parlange, M.B. \& Stricker H. (1996). On the Concept of Equilibrium Evaporation and the Value of the Priestley-Taylor Coefficient, Water Resour. Res., 32(1): 161-164, doi:10.1029/95WR02920.

Faybishenko, B. (2007). Climatic Forecasting of Net Infiltration at Yucca Mountain Using Analogue Meteorological Data, Vadose Zone Journal, 6: 77-92.

Faybishenko, B. (2010), Fuzzy-probabilistic calculations of water-balance uncertainty, Stochastic Environmental Research and Risk Assessment, Vol. 24, No. 6, pp. 939-952.

Ferson, S. (2002). RAMAS Risk Calc 4.0 Software: Risk assessment with uncertain numbers, CRC Press.

Ferson, S. \& Ginzburg, L. (1995) Hybrid arithmetic. Proceedings of the 1995 Joint ISUMA/ NAFIPS Conference, IEEE Computer Society Press, Los Alamitos, California, pp. 619-623.

Ferson, S.; Kreinovich, V.; Ginzburg, L; Myers, D.S. \& Sentz, K. (2003). Constructing probability boxes and Dempster-Shafer structures, SAND REPORT, SAND20024015 .

Gee, G.W.; Fayer, M.J.; Rockhold, M.L. \& Campbell, M.D. (1992). Variations in recharge at the Hanford Site. Northwest Sci. 66, pp. 237-250.

Gee, G.W.; Oostrom, M.; Freshley, M.D.; Rockhold, M.L. \& Zachara, J.M. (2007). Hanford site vadose zone studies: An overview, Vadose Zone Journal Vol. 6, pp. 899-905.

Guyonne, D.; Dubois, D. ; Bourgine, B.; Fargier, H.; Côme, B. \& Chilès, J.-P. (2003). Hybrid method for addressing uncertainty in risk assessments. Journal of Environmental Engineering 129: 68-78.

Hansen, S. (1984). Estimation of Potential and Actual Evapotranspiration, Nordic Hydrology, 15, 1984, pp. 205-212, Paper presented at the Nordic Hydrological Conference (Nyborg, Denmark, August 1984).

Hargreaves, G.H. \& Z.A. Samani (1985). Reference crop evapotranspiration from temperature. Transaction of ASAE 1(2), pp. 96-99.

Hoitink, D.J.; Burk, K.W ; Ramsdell, Jr, J.V; \& Shaw, W.J. (2003). Hanford Site Climatological Data Summary 2002 with Historical Data . PNNL-14242, Pacific Northwest National Laboratory, Richland, WA.

Jensen, M.E. \& Haise, H.R. (1963). Estimating evapotranspiration from solar radiation. J. Irrig. Drainage Div. ASCE, 89: 15-41.

Kaufmann, A. \& Gupta, M.M. (1985). Introduction to Fuzzy Arithmetic, New York: Van Nostrand Reinhold. 
Kingston, D.G.; Todd, M.C.; Taylor, R.G.; Thompson, J.R. \& Arnell N.W. (2009). Uncertainty in the estimation of potential evapotranspiration under climate change, Geophysical Research Letters, Vol. 36, L20403. doi:10.1029/2009GL040267

Linacre, E. T. (1977). A simple formula for estimating evaporation rates in various climates, using temperature data alone. Agric. Meteorol., 18, pp. 409--424.

Makkink, G. F. (1957). Testing the Penman formula by means of lysimiters, J. Institute of Water Engineering, 11, pp. 277-288.

Maulé C.; Helgason, W.; McGin, S. \& Cutforth, H. (2006). Estimation of standardized reference evapotranspiration on the Canadian Prairies using simple models with limited weather data. Canadian Biosystems Engineering 48, pp. 1.1 -1.11.

Neitzel, D.A. (1996) Hanford Site National Environmental Policy Act (NEPA) Characterization. PNL-6415, Rev. 8. Pacific Northwest National Laboratory. Richland, Washington.

Or D. \& Hanks, R.J. (1992). Spatial and temporal soil water estimation considering soil variability and evapotranspiration uncertainty, Water Resour. Res. Vol. 28, No. 3, pp. 803-814. doi:10.1029/91WR02585

Penman H.L (1963). Vegetation and hydrology. Tech. Comm. No. 53, Commonwealth Bureau of Soils, Harpenden, England. 125 pp.

Priestley, C.H.B. \& Taylor, R.J. (1972). On the assessment of surface heat flux and evaporation using large-scale parameters. Mon. Weather Rev. 100(2), pp. 81-92.

Sumner D.M. \& Jacobs, J.M. (2005). Utility of Penman-Monteith, Priestley-Taylor, reference evapotranspiration, and pan evaporation methods to estimate pasture evapotranspiration, Journal of Hydrology, 308, pp. 81-104.

Thornthwaite, C.W. (1948). An approach toward a rational classification of climate. Geogr. Rev. 38, pp. 55-94.

Turc, L. (1963). Evaluation des besoins en eau d'irrigation, évapotranspiration potentielle, formulation simplifié et mise à jour. Ann. Agron., 12: 13-49.

Walter, I.A.; Allen, R.G.; Elliott, R.; Itenfisu, D.; Brown, P.; Jensen, M.E.; Mecham, B.; Howell, T.A.; Snyder, R.L.; Eching, S.; Spofford, T.; Hattendorf, M.; Martin, D.; Cuenca, R.H. \& Wright, J.L. (2002). The ASCE standardized reference evapotranspiration equation. Rep. Task Com. on Standardized Reference Evapotranspiration July 9, 2002, EWRI-Am. Soc. Civil. Engr., Reston, VA, 57 pp. /w six Appendices. http://www.kimberly.uidaho.edu/water/asceewri/main.pdf.

Ward, A.L.; Freeman, E.J.; White, M.D. \& Zhang, Z.F. (2005). STOMP: Subsurface Transport Over Multiple Phases, Version 1.0, Addendum: Sparse Vegetation Evapotranspiration Model for the Water-Air-Energy Operational Mode, PNNL-15465.

Yager. R. \& Kelman, A. (1996). Fusion of fuzzy information with considerations for compatibility, partial aggregation, and reinforcement. International Journal of Approximate Reasoning, 15(2), pp. 93-122.

Zadeh, L. (1978). Fuzzy sets as a basis for a theory of possibility. Fuzzy Sets and Systems, 1, pp. 3-28.

Zadeh, L.A. (1986). A Simple view of the Dempster-Shafer theory of evidence and its implication for the rule of combination. The AI Magazine 7, pp. 85-90.

Zhu J.; Young, M.H. \& Cablk, M.E. (2007) Uncertainty Analysis of Estimates of GroundWater Discharge by Evapotranspiration for the BARCAS Study Area, DHS Publication No. 41234. 


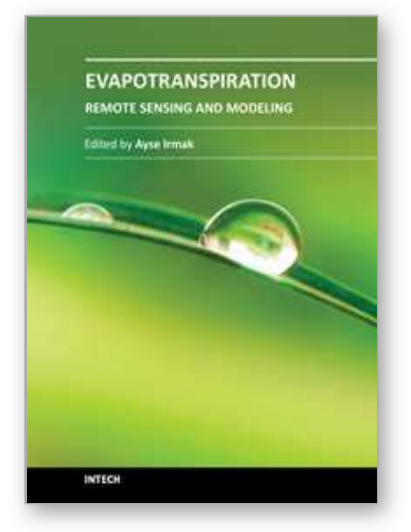

\author{
Evapotranspiration - Remote Sensing and Modeling \\ Edited by Dr. Ayse Irmak
}

ISBN 978-953-307-808-3

Hard cover, 514 pages

Publisher InTech

Published online 18, January, 2012

Published in print edition January, 2012

This edition of Evapotranspiration - Remote Sensing and Modeling contains 23 chapters related to the modeling and simulation of evapotranspiration (ET) and remote sensing-based energy balance determination of ET. These areas are at the forefront of technologies that quantify the highly spatial ET from the Earth's surface. The topics describe mechanics of ET simulation from partially vegetated surfaces and stomatal conductance behavior of natural and agricultural ecosystems. Estimation methods that use weather based methods, soil water balance, the Complementary Relationship, the Hargreaves and other temperatureradiation based methods, and Fuzzy-Probabilistic calculations are described. A critical review describes methods used in hydrological models. Applications describe ET patterns in alpine catchments, under water shortage, for irrigated systems, under climate change, and for grasslands and pastures. Remote sensing based approaches include Landsat and MODIS satellite-based energy balance, and the common process models SEBAL, METRIC and S-SEBS. Recommended guidelines for applying operational satellite-based energy balance models and for overcoming common challenges are made.

\title{
How to reference
}

In order to correctly reference this scholarly work, feel free to copy and paste the following:

Boris Faybishenko (2012). Fuzzy-Probabilistic Calculations of Evapotranspiration, Evapotranspiration - Remote Sensing and Modeling, Dr. Ayse Irmak (Ed.), ISBN: 978-953-307-808-3, InTech, Available from: $\mathrm{http}: / /$ www.intechopen.com/books/evapotranspiration-remote-sensing-and-modeling/fuzzy-probabilisticcalculations-of-evapotranspiration

\section{INTECH}

open science | open minds

\author{
InTech Europe \\ University Campus STeP Ri \\ Slavka Krautzeka 83/A \\ 51000 Rijeka, Croatia \\ Phone: +385 (51) 770447 \\ Fax: +385 (51) 686166 \\ www.intechopen.com
}

\author{
InTech China \\ Unit 405, Office Block, Hotel Equatorial Shanghai \\ No.65, Yan An Road (West), Shanghai, 200040, China \\ 中国上海市延安西路65号上海国际贵都大饭店办公楼405单元 \\ Phone: $+86-21-62489820$ \\ Fax: $+86-21-62489821$
}


(C) 2012 The Author(s). Licensee IntechOpen. This is an open access article distributed under the terms of the Creative Commons Attribution 3.0 License, which permits unrestricted use, distribution, and reproduction in any medium, provided the original work is properly cited. 